Research, part of a Special Feature on Public policies and management of rural forests: lasting alliance or fool's dialogue?

\title{
Patrimony for Resilience: Evidence from the Forest Agdal in the Moroccan High Atlas Mountains
}

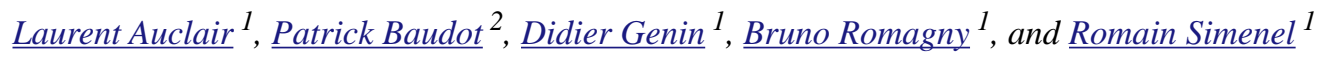

\begin{abstract}
Patrimony and resilience appear today as key concepts for understanding the dynamics of systems confronted with natural hazards. Nevertheless, the theoretical comparison between these concepts drawn from different epistemic approaches is lacking. Our aim is to interrelate resilience and patrimony concepts on the basis of a real example: the Agdal, a traditional forest management system in the Moroccan High Atlas. The role played by the Agdal in safeguarding the patterns of forest resource use by village communities from both external and internal conflicts, from natural hazards, and by securing a longterm supply of resource diversity is highlighted. This role shows the patrimonial character of the forest Agdal for the village communities and suggests an adaptive perspective. The patrimonial construction of the forest gives rise to management systems that allow a major place to experience social and environmental feedback, contributing to strengthened social-ecological system resilience and adaptability in the High Atlas Mountains. The notion of patrimony as a tool of resilience opens up a new interdisciplinary line of research.
\end{abstract}

Key Words: High Atlas; Morocco; patrimony; resilience; social-ecological system

\section{INTRODUCTION}

Drawn from epistemic approaches of different origins, patrimony and resilience are concepts that have rarely been put into proper perspective. The first, perceived as a transgenerational social construction, dates back to Henri Ollagnon's earlier work within the French-speaking scientific community (Ollagnon 1979). The proposed definition by this author remains a reference in the domain: "an ensemble of material and immaterial elements centered on the ownership titleholder [individual or human community], which converges to maintain and to develop its identity and its autonomy by adaptation, in time and space, to a changing universe" (Ollagnon 2000:339). More recently, some authors have connected the patrimony notion, considered as collective memory, to that of culture and civilization. From this point of view, it is important to study "how social groups have assembled patrimonies, broken them up and reassembled over time, patrimonies that are specific to their community, in order to guarantee the permanence of their identity in time and space" (Barrière et al. 2005:19).

The concept of resilience, drawn from the physical characteristics of materials and from ecology, has become widely used among the English-speaking scientific community in recent years, most notably by the Resilience Network. Following Holling's earlier work (1973), resilience has made its mark in the systemic analyses field and in the social-ecological systems (SES) approach (Folke et al. 2002), as an "integrated concept of humans in nature" (Berkes 2004). Resilience is defined as the SES capacity to absorb disturbance and reorganize while undergoing change so as to retain the same function, structure, identity, and feedbacks (Walker et al. 2004). The idea that both adaptation and transformation are essential for SES persistence has become the core of resilience thinking (Folke et al. 2010).

Key concepts for understanding the dynamics of systems confronted with uncertainties, patrimony, and resilience occupy a central place in the debate on environment and sustainable natural resource management. The two concepts are the basis of the action-focused approaches that have been significantly developed over the past decades: in particular patrimony management (de Montgolfier and Natali 1987, Weber 1996, Babin et al. 2002), adaptive and co-adaptive management (Olsson et al. 2004). In addition, the patrimonialization of nature and biodiversity, more recently of traditional knowledge, appear today as some of the main tools of sustainable development and conservation policies (Cormier-Salem et al. 2002, 2005).

Nevertheless, a theoretical comparison between resilience and patrimony concepts is dramatically missing from this field at the moment. The present article aims at interrelating these concepts on the basis of a real example: the Agdal, a traditional forest management system in the Moroccan High Atlas. The ubiquitous community practices of Agdal (plur. Igudlan/ Igdalen), in the Moroccan mountains, correspond to temporary restrictions with regard to specific resource use within a specific territory (Auclair 2011). The results of multidisciplinary research undertaken over the past decade in the valley of the Ait Bouguemmez (central High Atlas) are taken into account here, particularly research on forest areas (Cordier and Genin 2008, Romagny et al. 2008, Aubert et al. 2009, Aubert 2010, Auclair et al. 2010, Hammi et al. 2010, Auclair and Alifriqui 2011, Genin et al. 2011a, Genin and Simenel 2011). 
As a first step, we will show the central position of natural resource use in the SES structure and functioning of the High Atlas, as well as Agdals' importance in forest resource management. In particular, we will highlight the key role played by Agdals in safeguarding the use of forest resources by village communities. This latter property will be mobilized to show the forest Agdal's patrimonial character for village communities, and finally, the central place of this socialecological patrimony in building SES resilience and adaptability in the High Atlas mountains.

\section{SOCIAL-ECOLOGIAL SYSTEMS STRUCTURED BY THE PATTERNS OF USE OF NATURAL RESOURCES: THE AÏT BOUGUEMMEZ VALLEY IN THE CENTRAL HIGH ATLAS}

\section{A mountainous environment}

The Ait Bouguemmez valley is located at the heart of the central High Atlas, between 1800 and $2200 \mathrm{~m}$ altitude in the rural district of Tabant, Province of Azilal. It is surrounded by high mountain ranges rising to over 3000 meters altitude, which render it particularly isolated. The Mediterranean highland-type climate presents two limiting factors for agricultural activities: the annual rainfall varies between 500 and $750 \mathrm{~mm}$, depending on altitude, with an irregular distribution in time and space (mainly in autumn and spring), and a huge temperatures amplitude exists (extreme temperatures range from $-15^{\circ}$ to $+42^{\circ} \mathrm{C}$ ). As a result, this region is severely exposed to natural hazards: recurrent drought, cold and snow, as well as sudden and devastating flood periods.

The landscape's vertical structure determines a stratified pattern within the ecological environment along the altitude gradient, and complementary natural resource use patterns: rangelands, forests, and agricultural lands. The upper parts resemble extensive rangelands, mainly composed of spiny xerophytic vegetation and reduced areas of short grasslands $(A \operatorname{lmu})$. The wooded areas above the villages are composed of holm oak (Quercus ilex) and three juniper species (Juniperus thurifera, Juniperus oxycedrus, and Juniperus phoenicea), the composition of which varies according to ecological conditions, orientation, and altitude. The forest areas provide the resource diversity necessary to rural societies: (1) wood used for cooking food and heating dwellings, (2) poles and beams used for timber construction, and (3) leaf fodder, an essential backup resource for winter feeding of herds (Genin et al. 2011a). The forest understory is grazed by livestock for most of the year. The bottom of the valley is devoted to irrigated agriculture.

\section{A Berber agropastoral society}

This valley is broadly oriented East-West with a length of about $40 \mathrm{~km}$. It shelters more than thirty villages stretching along the bottom of the valley, with a population of approximately 15,000 inhabitants (Figure 1). Berber-speaking people living there are typically transhumant or sedentary agropastoralists, even though other activities linked to ecotourism and migration have developed during the past thirty years, inducing structural and economic changes in the local society. The production systems are based on a combination of relatively intensive agriculture by irrigation, and extensive sheep and goat farming on the upper slopes and rangelands (Bourbouze 1999). Annual (wheat, barley, alfalfa, potatoes) and tree (apple, walnut) crops are cultivated in the bottom of the valley, irrigated by channels (seguia) diverting water from the river, along some plots of dry cultivation (bour) in the lower parts of the slopes. Livestock farming, mainly sheep and goat but with an increasing number of cattle, represents an important element of these farming systems, and is based on diversified forage resources coming from both agricultural fields, and surrounding or remote (transhumance) rangelands and forests (tree foliage). The use of natural resources still constitutes the mainstay of livelihood systems and is an important issue, both in the short and long term.

Fig. 1. Location of the Ait Bouguemmez valley (central High Atlas, Morocco) (source: Hammi 2007)

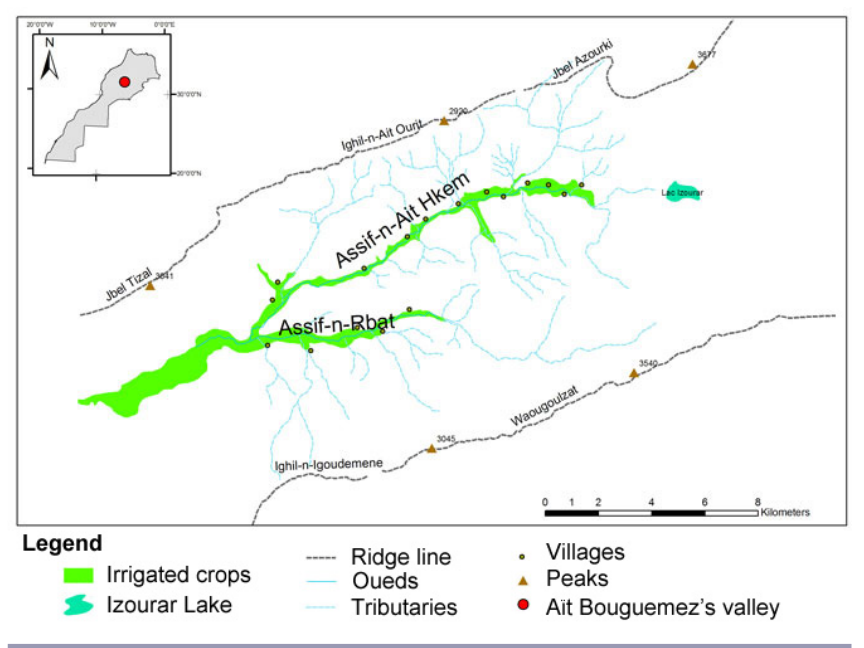

The Ait Bouguemmez valley has conserved several of the characteristics of traditional Berber social functioning. It is characterized by active community institutions that govern local life and the uses of natural resources (Fay 1986, LecestreRollier 1992, Auclair 1996, Garrigues-Cresswell and Lecestre-Rollier 2001, Riaux 2006). In parallel with the stratification of resources, the ownership and management styles are also stratified as substantiated by the mix of segmental anthropological approaches (Gellner 1969) and the analysis grid for the property laws established by the Common Pool Resources School (Schlager and Ostrom 1992). The segmental pattern is a social and political structure characterized by social groups overlapping segments such as: 
family, village, fraction, tribe, etc., organized like Russian dolls. The segmental structure is spatially projected, expressing the various social segments' territorial control and resource management (Auclair 2000). In the High Atlas, the territories are set up perpendicularly to the main mountain axes, from the high altitude pastures down to the valley floor. Control over the resources moves up the segmental scale in phase with the increasing height of the slope and distance from the villages. One may schematically distinguish three main resource spaces along the altitude gradient (Figures 2 and 3):

Fig. 2. Segmentary level control and territorial organization of the upper valley of the Ait Bouguemmez (source: Auclair and Hammi 2008)

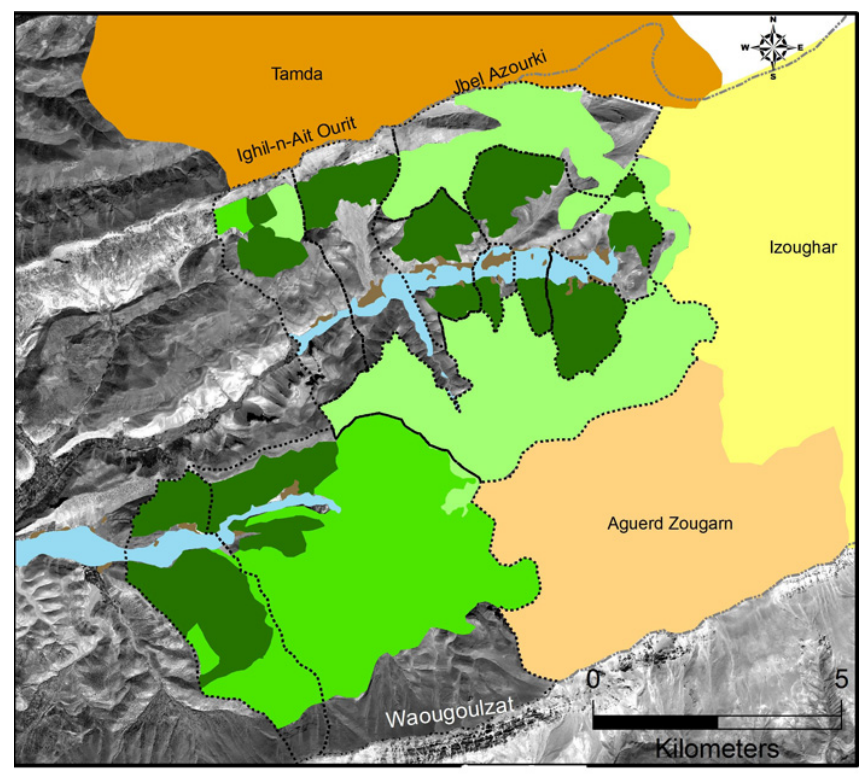

Village forest Agdal Inter-village outside-Agdal Village outside-Agdal Inter-village pastoral Agdal Inter-tribe pastoral Agdal Inter-tribe pastoral outside-Agdal

- Agricultural land on the valley floor: family appropriation;

- Forests: village community appropriation;

- Rangelands: inter-village common appropriation on the slopes, inter-tribal common appropriation on the summer pastures.

The use and management of natural resources assume a particular importance for the development and reproduction of local societies. It is hence not surprising that people have developed highly refined tools in this domain, among these the Agdal practice is the archetypal example.

\section{THE AGDAL AND SAFEGUARDING FOREST RESOURCE USE PATTERNS}

\section{Roots of an endogenous concept}

Agdal is a Berber word that is frequently associated with grasslands and pastoral activities. In the local language, the verb gdel means "to graze livestock in a good pasture" (Laoust 1920). It takes its roots from the remote history of North African pastoral societies who have always had the necessity of protecting and deferring the use of certain pastoral areas in order to make forage available for their livestock at critical periods. It is not surprising that the Agdal system has been mainly documented in pastoral contexts (Gellner 1969, Bourbouze 1999, Ilahiane 1999, Mahdi 1999, Venema 2002). However in southern Morocco, it refers also to a diversified range of resources and ecosystems. Agdal management can be applied to forest, fruit, agricultural, forage, medicinal plant, and even marine resources.

Genin and Simenel (2011) proposed a global definition for Agdal as "a generic Berber term designating areas where access rights and uses of natural resources are governed by a local institution - usually the village, inter-village or intertribe assembly - which fixes rules concerning periods and modalities of differentiated natural resource exploitation". It always involves a temporary respite from use with the aim of conserving or deferring the use of resources for critical periods. Customary laws limit the boundaries of the Agdal and fix its closing and opening dates.

The Agdal concept is inseparable from the representation and belief systems of Berber rural societies (Mahdi 1999, Dominguez et al. 2010, Simenel 2010). It expresses the links between two orders of fundamental Berber values (Jamous 2002): honor, which guides exchanges and relationships between human beings, and baraka which guides the ones between men and God, by intermediary of Saints and genies (jnoun) who are usually devoted to the protection of sanctuary Agdals (Simenel 2010). Those latter areas, as "domains of the forbidden" placed under the intervention of Saints, present the properties of the "sacred things" described by Durkheim (1912).

It is noteworthy that $\mathrm{Agdal}$ is probably a very ancient practice, found in all the Berber-speaking regions of North Africa and Sahara; furthermore, it is evident in rock graves which are more than three thousand years old and are commonly found in the vicinity of High Atlas pastoral Agdals. The concept has continued throughout the centuries, with successive appropriations and adaptations (Auclair 2011).

Agdal offers a holistic conceptual framework integrating ecosystems and resources, knowledge and practices, rules and 
Fig. 3. Cross section of the main resource spaces and appropriation levels in the upper valley of the Ait Bouguemmez (adapted from Romagny et al. 2008).

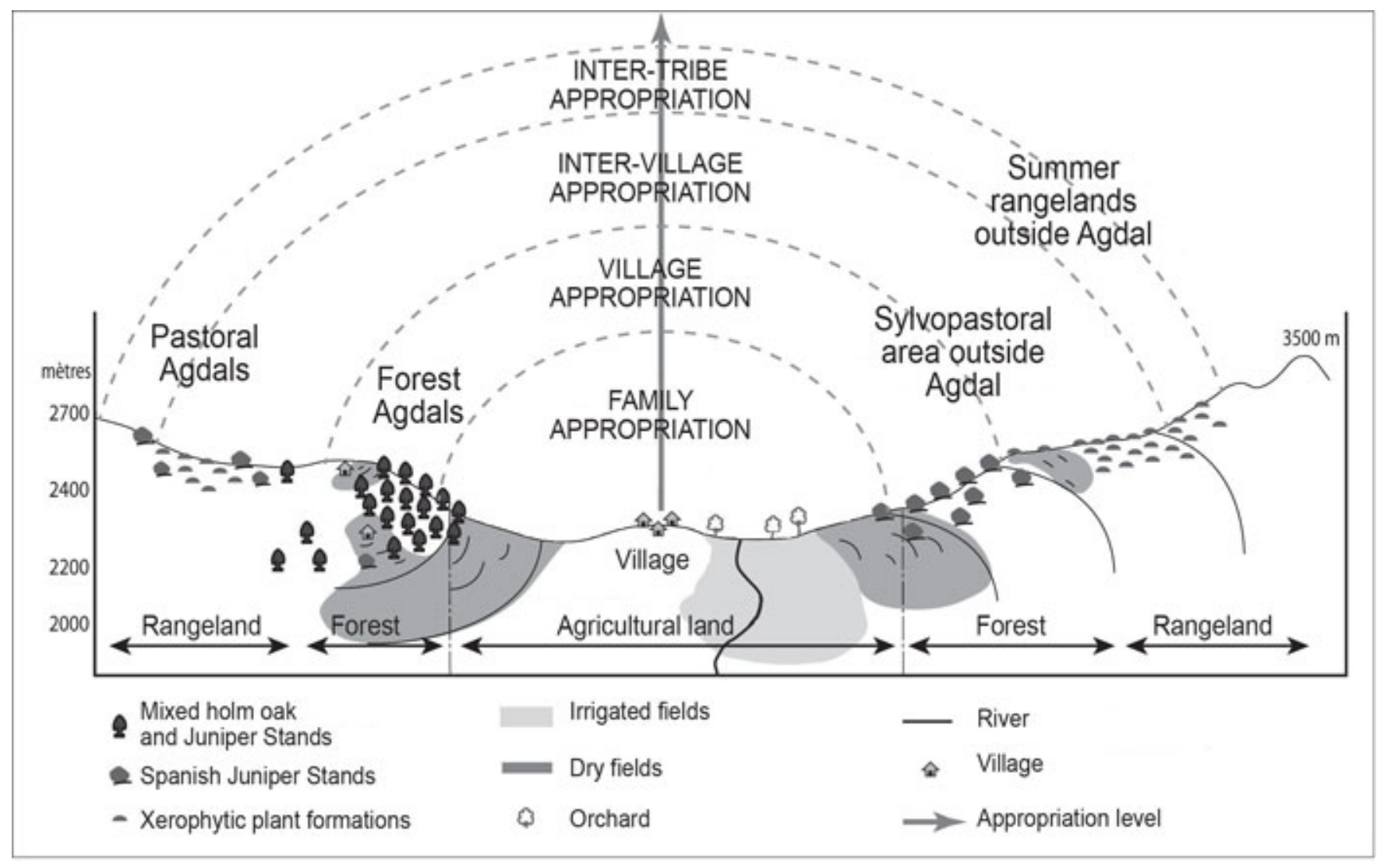

institutions, representations and beliefs, within a territory. This type of land and resource management offers ecological responses to environmental constraints, which show common features with the contemporary new opportunistic range management at disequilibrium approach (Benhke et al. 1993, Roe et al. 1998), and adaptive arrangements to social dynamics, conforming to a holistic approach beyond nature and culture (Descola 2005). It shares several similarities with other concepts and practices in the semitic cultural area, such as Ethiopian protected "church forests" (Bongers et al. 2006) and the Hema pastoral system found in the Middle East (Masri 1991), but also in other parts of the world, such as the Swiss alpine rangeland management integrating private and common property regimes (Netting 1981), or the Aynuqa system found in the Andes for managing climatic and social risks and soil fertility (Rivière 1994).

\section{A spatialized differentiation within the rural territory}

In the Ait Bouguemmez valley, a twofold customary regime system (Agdal/ outside-Agdal)) characterizes the forest and pastoral territories managed by the communities at different segmental scales (Table 1, Figures 2 and 3):
- The Agdal territory is placed under one social group's exclusive control; it is subject to temporary deferred grazing or forest product use. Customary assemblies (jmâa), including all the heads of family of the "proprietary" segments are the forum for the exercise and negotiation of rights at the collective level. A control and sanction system governs the collective rules. Each village in the valley possesses one or two forest Agdals with an area ranging from 20 to 200 ha (Figure 2), territories treated as deferred use areas for most of the year (prohibition on cutting live wood and green foliage). The exploitation of Agdal resources, including leaf fodder, firewood, and construction timber, is subject to a wide range of rules imposed by the village assemblies, which were described in detail by Cordier and Genin (2008) for forest resources. To summarize, they can refer to at least four aspects: periodicity of use, quantity of harvest, division of $\mathrm{Agdal}$ into sectors in order to allow rotational cutting, and tree species to be cut.

- The outside-Agdal territory may be placed under one social group's exclusive control, but within the "frontier" 
areas situated at the confines of segmental group's territories, this type of space is often claimed and exploited by several competing groups. The outsideAgdal area is open for use throughout the year and is not governed by exploitation rules, except for communities that have been able to keep exclusive control of this kind of space, and where some rules have been established by the village assembly in order to limit forest depletion (Cordier and Genin 2008).

The rights to access to different resources (forests, rangelands, irrigation water) are subject to ongoing negotiations, and give rise to numerous inter-community agreements and an integrated and cross-scale management system. However, the patterns of forest use and ecological status have been subject to drastic changes. Over the past few decades, the Ait Bouguemmez valley has become increasingly open to outside influences with accelerated social, economic, and institutional changes which have been analyzed by Riaux (2006), Romagny et al. (2008), Aubert et al. (2009), and Aubert (2010).

Table 1. Customary status (Agdall outside Agdal) and segmentary level control of the main resource spaces in the Aït Bouguemmez valley

\begin{tabular}{|c|c|c|c|}
\hline & Village & Inter-villages & Inter-tribes \\
\hline Agdal & $\begin{array}{l}\text { Village } \\
\text { forest } \\
\text { (exclusive } \\
\text { use) } \\
\text { (1 to } 2 / \\
\text { village) }\end{array}$ & $\begin{array}{l}\text { Pastoral Agdal of } \\
\text { Aguerd Zougarne } \\
\text { (shared use } \\
\text { between } 10 \\
\text { villages) }\end{array}$ & $\begin{array}{l}\text { Pastoral Agdal of } \\
\text { Tamda } \\
\text { (shared with Aï Atta } \\
\text { and Aït Mohamed } \\
\text { tribes) }\end{array}$ \\
\hline $\begin{array}{l}\text { Outside } \\
\text { Agdal }\end{array}$ & $\begin{array}{l}\text { Village } \\
\text { forest } \\
\text { (exclusive } \\
\text { use) }\end{array}$ & $\begin{array}{l}\text { Forest and } \\
\text { rangeland areas } \\
\text { (shared use with } \\
\text { neighboring } \\
\text { villages) }\end{array}$ & $\begin{array}{l}\text { Rangeland of } \\
\text { Izoughar } \\
\text { (shared with Ait Atta } \\
\text { tribes from Southern } \\
\text { facing High Atlas) }\end{array}$ \\
\hline
\end{tabular}

\section{Resource safeguarding functions of forest Agdals}

"The Agdal is the community safeguard". This affirmation, frequently expressed by inhabitants, suggests a systemic $\mathrm{Agdal}$ interpretation as a safeguard for the community against the random aspects of natural disturbances. In the Ait Bouguemmez valley, four main arguments demonstrate the key roles of Agdals in safeguarding the use of forest resource systems:

\section{Long-term forest resource conservation}

The deferment of seasonal use in the forest Agdals causes longterm ecological effects. The forest cover diachronic analysis on the basis of aerial comparison and remote sensing documents from 1964 to 2002 (Hammi et al. 2007, 2010) shows highly contrasting dynamics according to the customary forest status. The Agdal areas are characterized by
Fig. 4. Dynamics of the tree cover in the upper valley of the Aït Bouguemmez between 1964 and 2002 (adapted from Hammi et al. 2010).

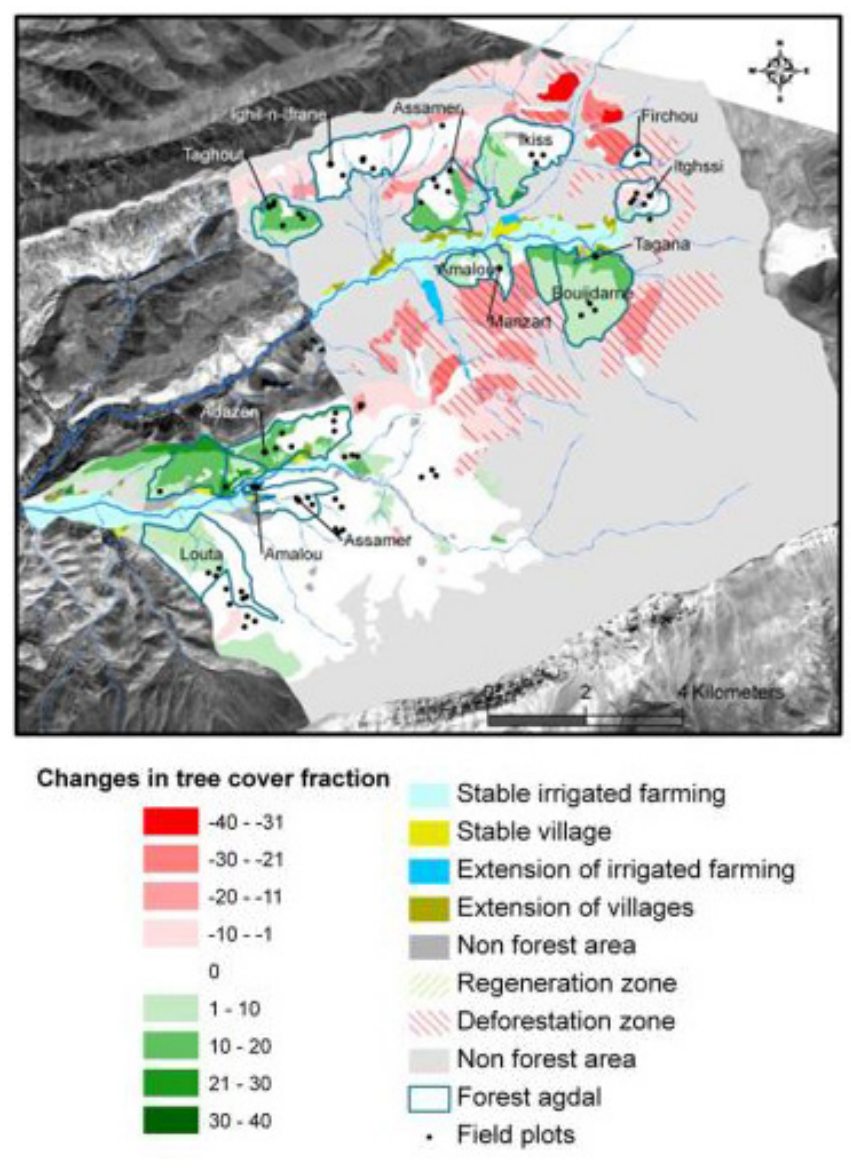

tree cover mean expansion, whereas the outside-Agdal areas have suffered a marked reduction in forest cover (Figures 4 and 5). The long-term maintenance of tree cover in the Agdals is accompanied by the maintenance of available biomass in these areas, guaranteeing temporal continuity of systems, and the provision of forest products in a strong demographic growth context (Aubert 2010).

The constitution of a stock of resources as a safeguard against natural hazards

The deferred use of resources in the Agdal provides a consistent reserve to cope with sudden disturbances. From this point of view, the Agdal is a kind of emergency kit, particularly useful in the harsh Moroccan Atlas. In the absence of large fodder stocks, and considering that many livestock farmers have abandoned winter transhumance over the past decades, the leaf fodder from holm oak and juniper, protected in the Agdal forest located in the village's immediate proximity, offers the means to feed animals in the event of heavy 
snowfalls (Genin et al. 2011a). The leaf fodder exploitation rules and Agdal opening and closing periods are dovetailed to snow episodes, with a wealth of detail on harvesting spatial modalities (Table 2).

Fig. 5. Patterns of change in the mean tree coverage according to customary status (Agdal/ outside Agdal) between 1964 and 2002 (adapted from Hammi et al. 2010).

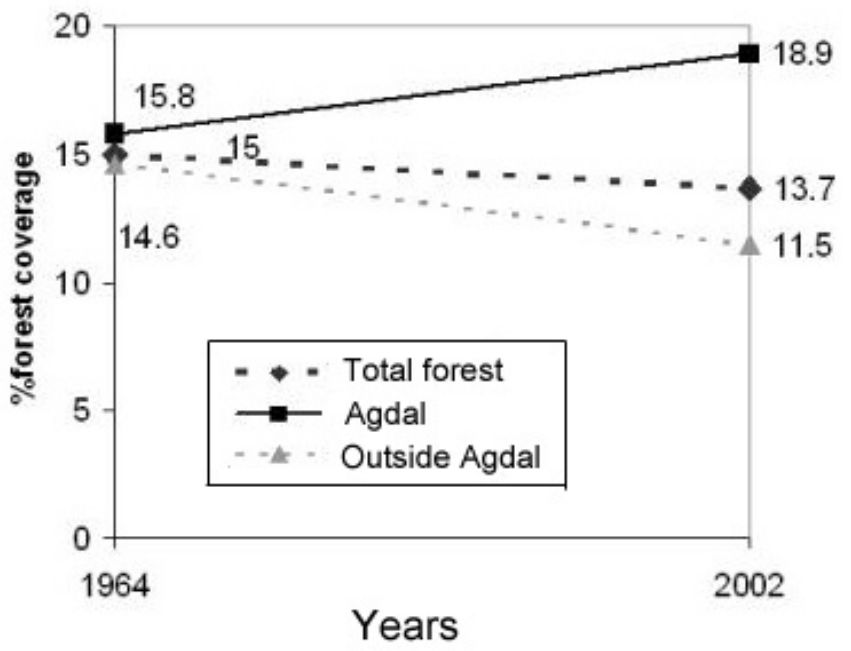

In certain villages that are well-endowed with forest resources, collective timber cutting is carried out periodically in the forest Agdals. The product can be shared among the community families or sold. In the latter case, the money obtained contributes to the village's financial reserves and is used to cover collective costs, or to carry out community projects. In these examples, the money obtained by the felling of Agdal trees constitutes a collective revenue source and a "safety net" for the village community.

\section{The diversity of ecological environments and complementary resource shaping}

The traditional forest management system is the basis of a spatial and functional duality in the forest area within the villages territories. This duality includes complementary ecological environments and resource spaces (Agdal/ outsideAgdal) associated with exploitation practices, and original ecological and forestry knowledge (Cordier and Genin 2008, Genin and Simenel 2011).

The forest areas managed under the Agdal system are characterized by relatively well-balanced proportions with regard to the tree morphotypes (Genin et al. 2011b). The physiognomy of the outside-Agdal forest areas is very different. Here, the landscape is usually made up of matorral comprised of shoots on stumps of holm oak and juniper that supply most of the firewood and leaf fodder for the population, as well as providing important grazing areas.

Genin and Simenel (2011) have shown that, in certain villages, forest territory is clearly subdivided into compartments, individualized from a morphological point of view, and characterized by exploitation practices and specific management modes. The latter determine the differentiated resource space patterns providing villagers with the range of diversified products necessary to maintain their livelihood. They hence play a role in the patchy landscape constitution within the village territory (Figures 6 and 7). This landscape patchwork is the basis of the systemic biodiversity that is one of the biodiversity components (Blondel 2006).

Fig. 6. Complementary resources of landscape patchiness (photography by Laurent Auclair).

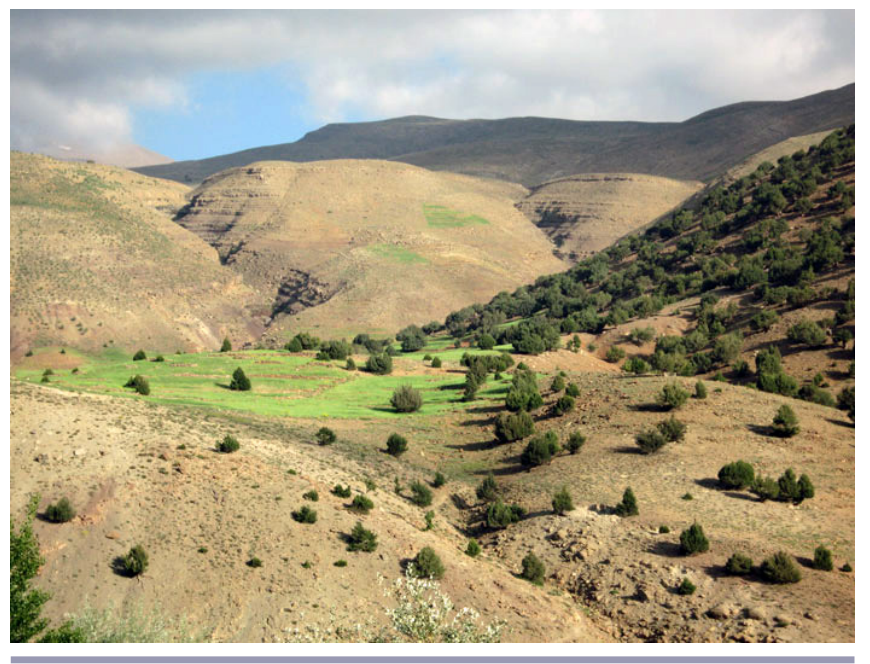

Fig. 7. Overview of the diversified landscape found in the Ait Bouguemmez valley (photography by Didier Genin).

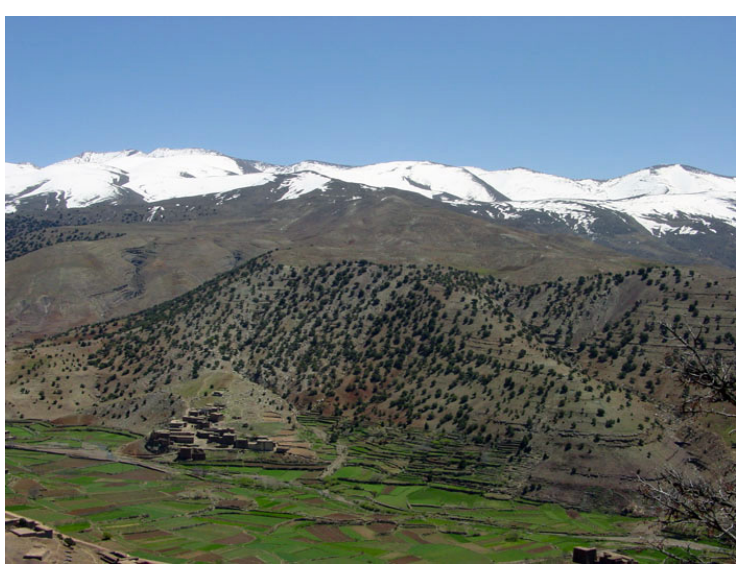


Table 2. Diversity of village rules for tree foliage recollection in the upper valley of the Aït Bouguemmez (extracted from Cordier \& Genin 2008).

\begin{tabular}{|c|c|c|}
\hline Village & Forest 'Outside Agdal' & Forest "Agdal" \\
\hline \multirow[t]{3}{*}{ Rbat n Oufela } & O : October to April & $\mathrm{O}$ : only if snow \\
\hline & F : Cutting: 2 days/week & $\mathrm{F}:$ every day \\
\hline & Q : 1 human or donkey load per household & $\mathrm{Q}:$ no restrictions \\
\hline \multirow[t]{3}{*}{ Akourbi } & $\mathrm{O}:$ October to March & $\mathrm{O}:$ only if snow \\
\hline & $\mathrm{F}:$ No restriction & F : every day \\
\hline & $\begin{array}{l}\text { Q : Free amount, but use of mule or donkey } \\
\text { forbidden }\end{array}$ & Q : Quantities depending upon size of family flock \\
\hline \multirow[t]{4}{*}{ Ibaqalliun } & Reduced surface & O : Only if snow, decision by the community \\
\hline & O: No restriction where cutting is authorized. & representative (Naïb) : 6-10 days/year \\
\hline & An area has been fully excluded from & Q : Free amounts \\
\hline & harvesting due to its advanced degradation. & One Agdal has been closed for many years \\
\hline \multirow[t]{3}{*}{ Taghoulid } & $\mathrm{O}$ : only if snow & $\mathrm{O}:$ Only if snow \\
\hline & $\mathrm{F}, \mathrm{Q}:$ No restriction & $\mathrm{Q}:$ No restriction \\
\hline & & $\mathrm{C}$ : Rotation between 2 sectors \\
\hline \multirow[t]{3}{*}{ Ifrane } & O : November to March & $\mathrm{O}:$ Only if snow \\
\hline & Q : 1 to 3 loads/household depending upon & Q : 1 to 3 loads/household depending upon flock size \\
\hline & flock size & $\mathrm{C}: 2$ sectors : 2 opened per year \\
\hline \multirow[t]{4}{*}{ Aït Ouchi } & O : October to April & $\mathrm{O}:$ Only if snow \\
\hline & $\mathrm{F}, \mathrm{Q}:$ No restriction & Q : 1 to 3 loads/household depending upon flock size \\
\hline & $\begin{array}{l}\text { Current negotiation for more restrictive rules } \\
\text { because of degradation }\end{array}$ & $\begin{array}{l}\text { C : Only } 1 \text { Agdal opened per year ( } 2 \text { Agdals on the village } \\
\text { territory) }\end{array}$ \\
\hline & & E : Some years only holm oak cutting authorized \\
\hline \multirow[t]{5}{*}{ Ighirine / Iguelwane } & O : November to March & $\mathrm{O}:$ Only if snow \\
\hline & $\mathrm{F}, \mathrm{Q}:$ No restriction & $\mathrm{C}: 2$ sectors opened per year (on 6 ) \\
\hline & & $\mathrm{F}: 1$ day/week \\
\hline & & Q : 2 to 3 loads per household (annual decision of the \\
\hline & & E : Only holm oak \\
\hline \multirow[t]{2}{*}{ Aït Ouham } & Almost no availability & O : Very scarce opening (12 ultimate years of exclosure) \\
\hline & & 1 to 10 days if particularly heavy snowfall \\
\hline Zaouit Alemzi & Almost no availability & $\begin{array}{l}\text { O : Only one Agdal opened per year ( } 2 \text { Agdals in the } \\
\text { village territory) if snowfall event }\end{array}$ \\
\hline
\end{tabular}

O: periods of opening; F: Week frequency of authorization of cutting; Q: amounts authorized; C: eventual rota schemes for the use of Agdals; E: Tree species to be exploited

Safeguarding rights and conflict management with regard to resources

In the context of demographic growth, both inter- and intracommunity conflicts and competition over forest resources represent a constant threat capable of affecting the sustainability of forest resources. This threat is contained and managed, to a certain extent, by the maintenance of the forest Agdals.

Inter-community conflict is managed as a result of the exclusive village control over Agdals. In the forest Agdal, the safeguarding of rights is guaranteed: (1) in space, through the exclusive control of the Agdal territory (establishment of a spatial frontier) by a clearly identified village community (establishment of a social frontier), and (2) in time, by the inter-generational transmission of these rights within the village community. Forest resource exploitation is strictly reserved for village community members, who are the operational and collective management right titleholders. Inter-village conflicts are contained by the social conditions that clarify access to the resources. The Agdal concept represents a certain security for the users.

Internal conflict is managed through the fair allocation of resources. Within the Agdal users community, the rules for 
resource exploitation and sharing are based on egalitarian values that make it possible to limit conflict and to manage internal competition. The Agdal opening date, decided by all, is an effective way to put all the users on an equal footing. In addition, the concern for equitable sharing of $\mathrm{Agdal}$ resources has led the villagers to develop a highly detailed quota system for leaf fodder harvesting by each household. Depending on the village, quotas are the same for all families, guaranteeing perfect equality, or are established on the basis of the size of a family's flocks (Table 2).

\section{The forest Agdal as a village community patrimony}

This Agdal interpretation, as a buffer against natural hazards and a decentralized territorial practice aimed at safeguarding the use of the forest resource system, is in strict conformity with the patrimony definition proposed by Ollagnon (2000). By safeguarding the system of use of forest resources in time and space, the Agdal makes an essential contribution to the communities' autonomy and identity maintenance, and hence to their social reproduction because they are highly dependent on the integrity of resource availability. The Agdal enables the village community to control its territory and to envisage, on a long-term basis, a pool of common resources and a range of modes of conservation and exploitation. This governance mode constitutes a support for community solidarity, strengthening group autonomy and cohesiveness over time.

In addition, the following two points demonstrate the extent to which the Agdal is of fundamental importance for the cultural construction and maintenance of the Berber community identity.

The Agdal place in the collective memory and the perception of community origin

In the Ait Bouguemmez valley, the forest Agdals are perceived as "very ancient". Their presence in the collective memory, according to the inhabitants, is associated with the village community's foundation, as united and indivisible as the trees of the Agdal. The surveyed people see the memory transmission of this twofold foundation (Agdal-community) to future generations as a duty. "We have received the Agdal as our heritage from our ancestors and should pass it on to our children".

The Agdal protection status supported by local values and beliefs

The mosque, a religious and sacred place, and the symbol of village unity (Rachik 2003), occupies a central position in community governance. The mosque is the Jmaâ meeting place, where communal decisions are deliberated and made after the collective Friday prayers; it is also the meeting place for the men who stay up during the long winter nights around a permanent fire that symbolizes community unity and permanence. In all the villages within the valley, the wood for the mosque is exclusively collected in the forest Agdals. The honor code, as well as religious and ritual practices underpin the Agdal rules, and more generally reinforce the protection status of the community institutions (cemetry, mosque, Agdal), which are the collective memory and guarantors of the village identity.

In summary, the forest Agdal holds all the attributes of a community heritage in order to "conserve to transmit" (Cormier-Salem et al. 2002, Auclair et al. 2010): (1) a key role in the reproduction of village communities in space and time, (2) a central place in the collective memory and perception of local history, and (3) a protection status supported by common values and beliefs.

\section{The Agdal patrimony as a tool of SES resilience and adaptability \\ SES resilience factor}

On the basis of the four points developed previously, the Agdal patrimony builds use systems which contribute to forest resource resilience, offering the means to respond to: (1) biological and climatic hazards affecting resources and their use, and (2) demographic and socio-political crises resulting in increased conflicts and competition with regard to resources. These two aspects are closely linked to the Agdal institution, which offers an overall territorial response. In the Agdal, conflict and competition over resources determine to a large extent the governance rules. They play a major role in the collective regulation system. Hence, as argued by several authors (Ilahiane 1999, Aubert 2010), insecurity linked to resources appears to be a necessary condition for Agdal activation.

In a society that is strongly dependent on local natural resources, social resilience and ecological resilience are closely interrelated. This interrelation is fully illustrated by the Agdal patrimony, which allows resource system resilience. This resilience type, at the core of social-ecological interactions, governs the functioning of rural societies, for which holistic patrimonial resource management is a condition for sustainability in a harsh environment.

The safeguarding of forest resources in the Agdal strengthens the village communities' resilience, viewed as the capacity of human communities to cope with and overcome various types of upheaval (Adger 2000, Carpenter et al. 2001).

The forest Agdal's explicit purpose is not the protection of the environment and biodiversity (Genin et al. 2011b), but the safeguarding of forest resource use systems in the Agdal has a marked ecological impact. By guaranteeing in the long term the maintenance of forest cover and ecosystem biodiversity (landscape patchiness), the Agdal patrimony contributes to the ecological system's resilience, which has historically been shaped by resource use patterns. 
The Agdal patrimonial management thus presents the characteristics of a resource management system "from a resilience point of view", as described by Berkes (2004):

- Locally developed usage rules, put into operation by the users themselves;

- A flexible resource management system;

- Accumulated ecological knowledge enabling a response to environmental constraints and hazards;

- Use of a complementary resource diversity system enabling livelihood maintenance and risk reduction;

- A qualitative management system sensitive to resource and ecosystem "feedback".

\section{SES adaptability factor}

As for the resilience concept, the definition of patrimony given by Ollagnon (2000) highlights the dynamic and adaptive processes at stake. Walker et al. (2004), and Folke et al. (2010) distinguish three characteristics for the SES trajectories: (1) resilience, (2) adaptability, i.e., "the capacity of a SES to learn, to combine experience and knowledge, to adjust its responses to changing external drivers and internal processes, and to continue developing within the current stability domain of attraction" (Berkes et al. 2003, Folke et al. 2010:2), and (3) transformability, i.e., "the capacity to create a fundamentally new system when ecological, economic or social structures make the existing system untenable" (Walker et al. 2004:5).

In the present example, the Agdal village patrimony contributes to the system's adaptability defined as the capacity of actors to influence and govern SES resilience (Walker et al. 2004). Three processes that show Agdal's incidence on the adaptive SES capacity may be distinguished:

- Flexibility: in the existing Agdals, the dates of opening/ closure, set of prohibitions, and rights regarding resource exploitation rules may be adjusted and adapted in order to cope with social and ecological variability, in an iterative process in which both traditional ecological knowledge (TEK) and traditional institutional knowledge (conflict management/ resolution in particular) are mobilized. The Agdal offers an institutional framework enabling adjustment of the resource management system in the face of socialecological disturbances. The Agdal is not only a traditional ecological knowledge system, "a KnowledgePractice-Belief complex" in the sense of Berkes et al. (2000), but also a traditional social-ecological knowledge system, a Knowledge-Practice-Institution-Belief complex.

- Innovation: in the face of situations of unexpected insecurity regarding the use of common resources, the Agdal provides the conceptual framework that is mobilized to orient the system toward the creation of a new Agdal. Each time, the same framework is reworked, modulated, and adapted according to the particular social-ecological configurations. In Berber rural society, "agdalization" is the privileged route toward the patrimonialization of common resources (Auclair et al. 2010). Agdal creation usually enables strengthening of SES resilience and adaptability to deal with resource use insecurity. But the Agdal may also be a tool for SES transformability. For example, in the Ait Bouguemmez valley, the Agdal concept was called upon recently to favor the transformation of production systems enabling the protection of young apple tree plantations in the irrigated area (Herzenni 2011).

- Accountability: Agdal and its arsenal of representations has the effect of reengaging the community as an actor in the governance of natural resources against the intrusion of external actors, primarily government and forestry officials, and to reinterpret some forms of disempowerment. For example afforestations, located in between-village conflicting areas, are also called "forester" Agdals by locals, which allow them to include foreign elements in order to conserve their proper interpretation of forest management.

The Agdal is both a social-ecological knowledge system and a patrimonial concept. Equipped with a full historical and symbolic representation corpus, the Agdal lies at the crossroads between ecological, sociological and cultural patrimony. Hence, it is a hybrid patrimony that can provide a real basis for SES resilience and adaptability.

\section{CONCLUSIONS}

The patrimony notion as a SES resilience and adaptability tool opens up a new interdisciplinary line of research. Patrimonialization cannot be reduced to a static vision of conservation and transmission of unchanging elements inherited from the past. The Agdal example suggests, as proposed in the Ollagnon definition, a dynamic and adaptive perspective. It shows that the patrimonial process of construction of a social-ecological object (the forest) may give rise to governance systems that allow an important role for experience and learning from social and environmental feedback, which contribute to strengthening the adaptive capacity as well as the social-ecological system's resilience.

At a time when the patrimony notion is increasingly successful, inspiring numerous government policies in Morocco and elsewhere, a number of questions are worth asking. To what extent are "exogenous" natural resources, biodiversity, or local knowledge patrimonialization processes, carried out and sustained by government intervention (Fairhead and Leach 2002), adaptability or transformability factors of SESs? How do they interfere with the "endogenous" patrimonialization processes? 
As a social-ecological patrimony, a support for the response to natural disturbances, adaptive, informal and decentralized, the Agdal enables the safeguarding of systems of use of resources by, and for, rural communities. The theoretical debate on the "SES's sustainability" is stimulated by such examples, which can be seen as classic examples presenting within a single spatialized object (a territory) a heuristic link between "Traditional Ecological Knowledge" (TEK), "Common Pool Resources Management" (CPRM), "patrimonial" and "adaptive management", and "CommunityBased Conservation" (CBC). This greatly facilitates the interdisciplinary process.

It would nonetheless be naïve to see in the Agdal, as practiced today in the Moroccan Atlas, an easily generalized plug-andplay tool for the sustainable management of resources. In the course of the $20^{\text {th }}$ century, the resource use systems in the rural environment, the production and livelihood systems, the resources, and the perception of what makes a resource have undergone profound changes. The systems of use are changing in relation to the production systems dynamic, the ever closer link between agriculture, sheep farming, and the market, the development of the tourism industry, and the mobility of seasonal populations or definitive emigration. Resource management systems are confronted with a regulatory and institutional framework that calls into question the autonomy of traditional local community governance. The introduction of sustainable development policies, whereby participative management and local knowledge are a priority, perpetuates the vision of a strict separation between nature and culture (Genin et Benchekroun 2007, Aubert 2010).

In the face of these changes, the Agdal presents an astonishing capacity for adaptation and for resilience, in particular due to the ritual and symbolic system plasticity and to the hybridization and cross-breeding of norms observed on the ground (Auclair et al. 2010, Simenel 2010). Nevertheless, the Agdal practices, increasingly linked to the national institutions from which they are claiming support and arbitration, are being transformed and are losing their autonomy.

In the perspective of "participative conservation" and "adaptive co-management" of the environment and of natural resources, the priority today is to invent tomorrow's Agdals, and to make the most of a patrimonial concept and a local knowledge system of which we have highlighted the symbolic power and heuristic value.

\section{RESPONSES TO THIS ARTICLE}

Responses to this article are invited. If accepted for publication, your response will be hyperlinked to the article. To submit a response, follow this link. To read responses already accepted, follow this link.

\section{ACKNOWLEDGMENTS}

This research was performed in Morocco in the framework of two programs conducted in partnership with the University Cadi Ayyad of Marrakech and the National School of Forestry Engineers (ENFI): the program AGDAL (2003-2007) supported by the French Institute for Biodiversity (IRD-IFB/ INRA no. 2886) and the program POPULAR (2007-2010) supported by the French Agency for Research (ANR-06PADD-014). Special thanks are due to Sanae Hammi and Guerino Sillere for their help with figures, and to Paul Trehin and Rupert Sharpe for the translation.

\section{LITERATURE CITED}

Adger, W. N. 2000. Social and ecological resilience: are they related? Progress in Human Geography 24(3):347-364. http:/ /dx.doi.org/10.1191/030913200701540465

Aubert, P. M. 2010. Action publique et société rurale dans la gestion des forêts marocaines: changement social et efficacité environnementale. Dissertation. AgroParisTech, Engref, Montpellier, France.

Aubert, P. M., M. Leroy, and L. Auclair. 2009. Moroccan forestry policies and local forestry management in the high Atlas: a cross analysis of forestry administration and local institutions. Small Scale Forestry 8:175-191. http://dx.doi.org /10.1007/s11842-009-9076-4

Auclair, L. 1996. L'appropriation communautaire des forêts dans le Haut Atlas marocain. Cahier des Sciences Humaines 32(1):177-194.

Auclair, L. 2000. Les ressources sylvopastorales au Maghreb: structure segmentaire et appropriation communautaire. Pages 123-140 in G. Rossi, P. Lavigne-Delville, and D. Narbeburu, editors. Sociétés rurales et environnement: gestion des ressources et dynamiques locales $d u$ Sud. Khartala, Paris, France.

Auclair, L. 2011. Un patrimoine socio-écologique à l'épreuve des transformations du monde rural. Introduction in L. Auclair and M. Alifriqui, editors. Agdal. Patrimoine socio-écologique de l'Atlas marocain. IRCAM-IRD, Rabat, Morocco, in press.

Auclair, L., and M. Alifriqui, editors. 2011. Agdal. Patrimoine socio-écologique de l'Atlas marocain. IRCAM-IRD, Rabat, Morocco, in press.

Auclair, L., R. Simenel, M. Alifriqui, and G. Michon. 2010. Agdal. Les voies imazighen de la patrimonialisation du territoire. Hespéris Tamuda 45:129-150.

Babin, D., M. Antona, A. Bertrand, and J. Weber. 2002. Gérer à plusieurs des ressources renouvelables, subsidiarité et médiation patrimoniale par récurrence. Pages 79-99 in M. C. Cormier Salem, D. Juhé-Beaulaton, J. Boutrais, and B. Roussel, editors. Patrimonialiser la nature tropicale. 
Dynamiques locales, enjeux internationaux. IRD Editions, Colloques et Séminaires, Paris, France.

Barrière, C., D. Barthélemy, M. Nieddu, and F. D. Vivien, editors. 2005. Réinventer le patrimoine. De la culture è l'àconomie, une nouvelle pensée du patrimoine? L'Harmattan, Paris, France.

Benhke, R., I. Scoones, and C. Kerven, editors. 1993. Range ecology at disequilibrium. New models of natural variability and pastoral adaptation in African savannas. ODI, London, UK.

Berkes, F. 2004. Rethinking community-based conservation. Conservation Biology 18(3):621-630. http://dx.doi.org/10.1111/ j.1523-1739.2004.00077.x

Berkes, F., J. Colding, and C. Folke. 2000. Rediscovery of traditional ecological knowledge as adaptive management. Ecological Applications 10(5):1251-1262. http://dx.doi.org/1 0.1890/1051-0761(2000)010[1251:ROTEKA]2.0.CO;2

Berkes, F., J. Colding, and C. Folke, editors. 2003. Navigating social-ecological systems: building resilience for complexity and change. Cambridge University Press, Cambridge, UK.

Blondel, J. 2006. The "design" of Mediterranean landscapes: a millennial story of human and ecological systems during the historic period. Human Ecology 34:713-730. http://dx.doi.org /10.1007/s10745-006-9030-4

Bongers, F., A. Wassie, F. J., Sterck, T. Bekale, and D. Teketay. 2006. Ecological restoration and church forests in northern Ethiopia. Journal of the Drylands 1(1):35-44.

Bourbouze, A. 1999. Gestion de la mobilité et résistance des organisations pastorales des éleveurs du haut Atlas marocain face aux transformations du contexte pastoral maghrébin. Pages 146-171 in M. Niamir-Fuller, editor. Managing mobility in African rangelands: the legitimization of transhumance. Immediate Technology Publications, London, UK.

Carpenter, S. R., B. H. Walker, J. M. Anderies, and N. Abel. 2001. From metaphor to measurement: resilience of what to what? Ecosystems 4:765-781. http://dx.doi.org/10.1007/s100 21-001-0045-9

Cordier, J. B., and D. Genin. 2008. Pratiques paysannes d'exploitation des arbres et paysages forestiers dans le haut Atlas marocain. Revue forestière française 60(5):571-588.

Cormier-Salem, M. C., D. Juhé-Beaulaton, J. Boutrais, and B. Roussel, editors. 2002. Patrimonialiser la nature tropicale. Dynamiques locales, enjeux internationaux. IRD Editions, Colloques et Séminaires, Paris, France.

Cormier-Salem, M. C., D. Juhé-Beaulaton, J. Boutrais, and B. Roussel, editors. 2005. Patrimoines naturels au Sud.
Territoires, identités et stratégies locales. IRD Editions, Colloques et Séminaires, Paris, France.

de Montgolfier J., and J. M. Natali, editors. 1987. Le patrimoine du futur. Approche pour une gestion patrimoniale des ressources naturelles. Economica, Paris, France.

Descola, P. 2005. Par delà la nature et la culture. Gallimard, Paris, France. http://dx.doi.org/10.3917/deba.114.0086

Dominguez, P., F. Zorondo-Rodriguez, and V. Reyes-Garcia. 2010. Relationships between religious beliefs and mountain pasture uses: a case study in the High Atlas mountains of Marrakech, Morocco. Human Ecology 38:351-362. http://dx. doi.org/10.1007/s10745-010-9321-7

Durkheim, E. 1968. Les formes élémentaires de la vie religieuse. PUF, Paris, France.

Fairhead, J., and M. Leach. 2002. Practising patrimony and biodiversity. The articulation of diverse local, national and international perspectives in Guinea, West Africa. Pages 343-370 in M. C. Cormier Salem, D. Juhé-Beaulaton, J. Boutrais, and B. Roussel, editors. Patrimonialiser la nature tropicale. Dynamiques locales, enjeux internationaux. IRD Editions, Colloques et Séminaires, Paris, France.

Fay, G. 1986. Ré-inventer la jma'a: réflexions pour le développement des milieux pastoraux. Bulletin d'Economie et de Sociologie du Maroc 159:113-125.

Folke, C., S. R. Carpenter, T. Elmqvist, L. Gunderson, C. S. Holling, B. Walker, J. Bengtsson, F. Berkes, J. Colding, K. Danell, M. Falkenmark, L. Gordon, R. Kasperson, N. Kautsky, A. Kinzig, S. Levin, K. Mäler, F. Moberg, L. Ohlsson, P. Olsson, E. Ostrom, W. Reid, J. Rockström, H. Savenije, and U. Svedin. 2002. Resilience and sustainable development: building adaptive capacity in a world of transformations. ICSU Series for Sustainable Development, No. 3. Scientific Background Paper commissioned by the Enviromental Advisory Council of the Swedish Government in preparation for WSSD. International Council for Science (ICSU), Paris, France. [online] URL: http://www.sou.gov.se/mvb/pdf/resiliens. pdf

Folke, C., S. R. Carpenter, B. Walker, M. Scheffer, T. Chapin, and J. Rockström. 2010. Resilience thinking: integrating resilience, adaptability and transformability. Ecology and Society 15(4):20. [online] URL: http://www.ecologyandsociety. org/vol15/iss4/art20/

Garrigues-Cresswell, M., and B. Lecestre-Rollier. 2001. Gérer les aléas. Les sociétés du haut Atlas marocain. Techniques et Culture 38:60-95.

Gellner, E. 1969. Saints of the Atlas. Weidenfeld and Nicolson, London, UK. 
Genin, D., and F. Benchekroun. 2007. De la parole aux gestes. Eléments de réflexion sur les dispositifs de gestion concertée des ressources forestières et pastorales au Maroc. IRD-France Coopération-ENFI, Rabat, Morocco.

Genin, D., B. Fouilleron, and L. Kerautret. 2011a. Un tempo bien tempéré. Place et rôles des Agdals dans les systèmes d'élevage des Ayt Bouguemmez (Haut Atlas central). In L. Auclair and M. Alifriqui, editors. Agdal. Patrimoine socioécologique de l'Atlas marocain. Royal Institute of Amazigh Culture (IRCAM) and French Institute of Research for Development (IRD), Rabat, Morocco, in press.

Genin, D., L. Kerautret, S. Hammi, J. B. Cordier, and M. Alifriqui. 2011b. Biodiversité et pratiques d'Agdal;: un élément de l'environnement à l'épreuve de ses fonctions d'utilité pour les sociétés rurales du haut Atlas central. In L. Auclair and M. Alifriqui, editors. Agdal. Patrimoine socioécologique de l'Atlas marocain. Royal Institute of Amazigh Culture (IRCAM) and French Institute of Research for Development (IRD), Rabat, Morocco, in press.

Genin, D., and R. Simenel. 2011. Endogenous Berber forest management and the functional shaping of rural forests in southern Morocco: implications for shared forest management options. Human Ecology 39(3):257-269. http://dx.doi.org/10. 1007/s10745-011-9390-2

Hammi, S., V. Simonneaux, M. Alifriqui, L. Auclair, and N. Montes. 2007. Évolution des recouvrements forestiers et de l'occupation des sols entre 1964 et 2002 dans la haute vallée des Aït Bouguemez (haut Atlas central, Maroc). Sécheresse 18(4):1-7.

Hammi, S., V. Simonneaux, J. B. Cordier, D. Genin, M. Alifriqui, N. Montes, and L. Auclair. 2010. Can traditional forest management buffer forest depletion? Dynamics of Moroccan High Atlas mountain forests using remote sensing and vegetation analysis. Forest Ecology and Management 260:1861-1872. http://dx.doi.org/10.1016/j.foreco.2010.08.033

Herzenni, A. 2011. L'Agdal à l'épreuve des stratégies familiales et de l'action collective. Le cas du douar Ifrane dans la vallée des Ayt Bouguemmez. In L. Auclair and M. Alifriqui, editors. Agdal. Patrimoine socio-écologique de l'Atlas marocain. IRCAM-IRD, Rabat, Morocco, in press.

Holling, C. S. 1973. Resilience and stability of ecological systems. Annual Review of Ecology and Systematics 4:1-23. http://dx.doi.org/10.1146/annurev.es.04.110173.000245

Ilahiane, H. 1999. The Berber agdal institution: indigenous range management in the Atlas mountain. Ethnology 38 (1):21-45. http://dx.doi.org/10.2307/3774085

Jamous, R. 2002. Honneur et baraka. Les structures sociales traditionnelles dans le Rif. MSH-Cambridge University Press, London, UK.
Laoust, E. 1983. Mots et choses berbéres. Société Marocaine d'Edition, Rabat, Morocco.

Lecestre-Rollier, B. 1992. Anthropologie d'un espace montagnard. Les Ayt Bou Guemmez du haut Atlas marocain. Dissertation. Université René Descartes, Paris, France.

Mahdi, M. 1999. Pasteurs de l'Atlas. Production pastorale, droit et rituel. Fondation Konrad Adenauer, Casablanca, Morocco.

Masri, A. 1991. The tradition of hema as a land tenure institution in arid land management: Syria. Food and Agriculture Organization (FAO), Rome, Italy.

Netting, R. 1981. Balancing on an Alp: ecological change and continuity in a Swiss Mountain. Cambridge University Press, New York, New York, USA.

Ollagnon, H. 1979. Propositions pour une gestion patrimoniale des eaux souterraines: l'expérience de la nappe phréatique d'Alsace. Pages 33-73 in Bulletin ministériel pour la rationalisation des choix budgétaires-36. La Documentation Française, Paris, France.

Ollagnon, H. 2000. La gestion en patrimoine commun de la qualité de l'eau dans un bassin. Pages 325-345 in M. Falque, and M. Massenet, editors. Les ressources en eau. Droits de propriété, économie et environnement. Dalloz, Paris, France.

Olsson, P., C. Folke, and F. Berkes. 2004. Adaptative comanagement for building resilience in social-ecological systems. Environmental Management 34(1):75-90. http://dx.d oi.org/10.1007/s00267-003-0101-7

Rachik, H. 2003. Symboliser la nation. Essai sur l'usage des identités collectives au Maroc. Editions Le Fennec, Casablanca, Morocco.

Riaux, J. 2006. Règles de l'Etat, règles de la communauté: une gouvernance locale de l'eau. Anthropologie comparée de deux systémes d'irrigation anciens en contexte d'intervention publique: vallée des Aït Bou Guemez (haut Atlas-Maroc), plaine de Vinça (Pyrénées-France). Dissertation. École des hautes études en sciences sociales (EHESS), Paris, France.

Rivière, G. 1994. Cultura y cultivos. El sistema de Aynuqa: memoria e historia de la comunidad. Pages 89-106 in D. Hervé, D. Genin, and G. Rivière, editors. Dinamicas del descanso de la tierra en los Andes. ORSTOM-IBTA, La Paz, Bolivia.

Roe, E., L. Hutsinger, and K. Labnow. 1998. High reliability pastoralism. Journal of Arid Environments 39:39-55. http://dx .doi.org/10.1006/jare.1998.0375

Romagny, B., L. Auclair, and A. El Gueroua. 2008. La gestion des ressources naturelles dans la vallée des Aït Bouguemez (Haut Atlas): la montagne marocaine à la recherche d'innovations institutionnelles. Mondes en développement 36 (141):63-80. http://dx.doi.org/10.3917/med.141.0063 
Schlager, E., and E. Ostrom. 1992. Property-rights regimes and natural resources: a conceptual analysis. Land Economics 68(3):249-262. http://dx.doi.org/10.2307/3146375

Simenel, R. 2010. L'origine est aux frontières. Les Aït Ba'amran, un exil en terre d'arganiers (sud Maroc). CNRS Editions-MSH, Paris, France.

Venema, B. 2002. The vitality of local political institutions in the Middle Atlas, Morocco. Ethnology 41:103-17. http://dx.d oi.org/10.2307/4153001

Walker, B. H., C. S. Holling, S. R. Carpenter, and A. P. Kinzig. 2004. Resilience, adaptability and transformability in socialecological systems. Ecology and Society 9(2):5. [online] URL: http://www.ecologyandsociety.org/vol9/iss2/art5/

Weber, J. 1996. Conservation, développement et coordination: peut-on gérer biologiquement le social? Proceedings of Colloque Gestion communautaire des Ressources Naturelles Renouvelables et Développement Durable, 24-27 June 1996, Harare, Zimbabwe. 